\title{
居住空間の換気能力に関する超過確率に基づく都市の風通しの評価法 AN EVALUATION METHOD BASED ON EXCEEDANCE PROBABILITIES FOR VENTILATION PERFORMANCE WITHIN URBAN AREAS
}

\author{
石田義洋 ${ }^{* 1}$ 加藤信介 ${ }^{* 2}$ 黄 弘 ${ }^{* 3}$ \\ Yoshihiro ISHIDA, Shinsuke KATO, Hong HUANG
}

\section{1. はじめに}

市街地の風環境の評価においては、対象市街地の上空風 の年間に亘る変動を考慮した検討が必要である。超過確 率を用いてこの変動を統計的に取り込んだ数多くの研究 が報告されている1，2，3，4)。これらの研究の多くは、強 風による風害効策を目的として進められて来た。

市街地の風環境は、複雑に入り組んだ建物や工作物など の影響を大きく受ける。特に住宅群を貫く生活道路などの 特定の領域では、換気能力の低下によって空気環境が悪化 し、住民の健康に悪影響をおよぼす可能性も考えられる。 筆者らは、弱風時の換気性能評価指標として、上空風 の駆動による居住空間の局所排出換気回数 ${ }^{5,6,7)}$ に対す る超過確率、および平均運動エネルギーに対する超過確 率のそれぞれを定義した ${ }^{8)}$ 。局所排出換気回数は清浄化 機能を代表する評価尺度、平均運動エネルギーは清涼化 機能を代表する評価尺度と考えられる ${ }^{8,99}$ 。そこでは、 密集市街地を模した簡単な形状の空堀モデルを設定して、 二種類の超過確率を用いて、その方位・形状、都市 (東 京、大阪）が換気能力に及ぼす影響を検討した ${ }^{8)}$ 。

続いて、現実の市街地に近い形状を有する三種類の密 集市街地モデルを設定し ${ }^{10)}$ 、局所排出換気回数に対する
超過確率 ${ }^{8)}$ を使用して、密集度の異なる市街地モデルの 換気能力を評価した ${ }^{11,12) 。 ~}$

本報では、密集市街地の超過確率の計算法を解説する とともに、局所排出換気回数、すなわち清浄化機能を代 表する評価尺度を基準とした超過確率の 4 都市における 計算例を示す。

\section{2. 新しい換気能力尺度}

\section{1 局所排出換気回数とその計算法}

図-1に市街地の検查空間とその清浄化機能を代表す ると考えられる局所排出換気量 (PFR) の概念を示す。 先に計算手順を述べる。

(1)市街地への流入プロファイルを設定し、図-1 の検査 空間を含む市街地全体（図-2４ 参照）の定常気流分布 を CFDにより計算する。

(2)検査空間内で、一様に污染質を発生させ、市街地全体 の濃度分布が定常になるまで、CFD で計算する。污染質 発生量は検查空間全体で $q[\mathrm{~kg} / \mathrm{s}]$ とする。

この手順で得られた検査空間の濃度の発生・排出状況 を模式的に表したものが図-1である。流入プロファイル を設定すると検査空間への流入出量 $Q$ が定まる。検査空

\footnotetext{
*1 東京大学生産技術研究所 特任教授

Project Professor, Institute of Industrial Science, University of Tokyo, Dr. Eng.

*2 東京大学生産技術研究所 教授

Professor, Institute of Industrial Science, University of Tokyo, Dr. Eng.

*3 東京大学生産技術研究所准教授

Associate Professor, Institute of Industrial Science, University of Tokyo, Dr. Eng.
} 
間への気流の流入出は再流入もあり複雑であるが、図-1 では再流入はないものとして、濃度 0 の気流の $Q\left[\mathrm{~m}^{3} / \mathrm{s}\right]$ の流入と平均流出濃度 $C_{\text {out }}[\mathrm{kg} / \mathrm{s}]$ の気流の同量の流出を仮 定している。このような単純な流入出の仮定のもとでは 污染質量の保存則から、式(1)が成り立つ。

式(1)の $Q$ は、平均濃度 $C_{\text {out }}$ の污染空気を排出して、検 査空間の平均濃度を $C_{p}$ に保つ換気能力と考えられる。

式(2)を考える。空間平均濃度 $C_{p}$ は容易に計算可能で ある。式(2)の $P F R\left[\mathrm{~m}^{3} / \mathrm{s}\right]$ は換気量の単位を持ち、かつ発 生量 $q[\mathrm{~kg} / \mathrm{s}]$ の值によらぬ検查空間固有の特性值となる。

風通しの悪、空間では、再流入もあり、空間内濃度が 分布するから、平均濃度 $C_{p}$ は流出濃度 $C_{\text {out }}$ より高くなる。 したがって、 $P F R<Q$ である。すなわち風通しの悪い空間 では、PFR は実際の流入量 $Q$ より小である。

また、検査空間への再流入がなく、検查空間内では完 全混合しているという十分に風通しのよい空間を仮定す ると、空間内濃度は一様となり、一様濃度が平均濃度 $C_{p}$ となる。流出濃度も $C_{o u}=C_{p}$ である。したがって、 $P F R=Q$ となり、検查空間への実際の流入出量と一致する。式(1) の $Q$ は設定した流入プロファイルにおける $P F R$ の上限 值と考えられる。これから、検査空間の特性值 $P F R$ をその 空間の風通しの良し悪しを計る尺度と見なすことができる。 PFR は検查空間といら局所領域の污染質を排出する換気 能力を表す尺度であり、換気量の単位を持つ特性値である。 よって、PFRは局所排出換気量と定義される。

さらに、局所排出換気量 $P F R$ を検査空間の体積 $V_{p}$ で除 して換気回数の単位に換算した換気能力の尺度

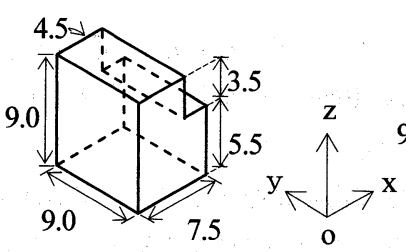

(a) 建物 A

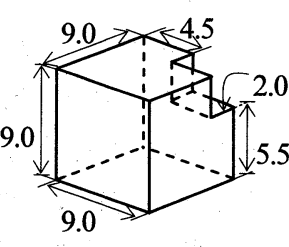

(b) 建物 B
図-2 建物形状

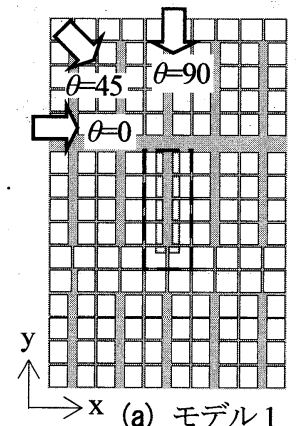

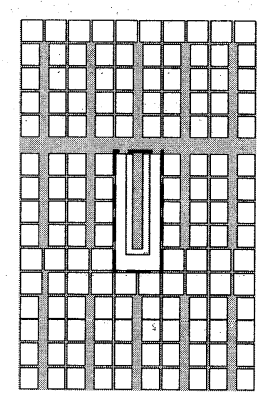

(b) モデル 2

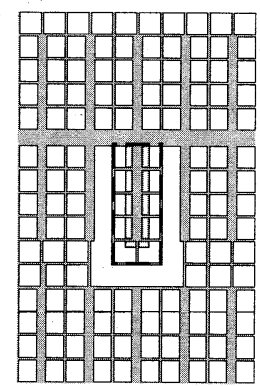

(c) モデル 3
図-3 密集市街地モデル (一反開発部分を破線で囲んで示す)

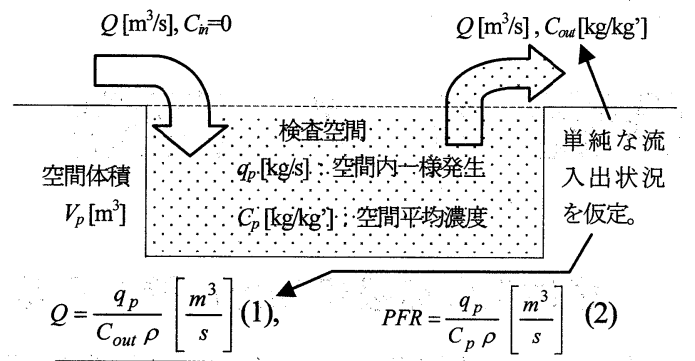

完全混合を仮定すると $C_{p}=C_{\text {out }}, P F R=Q\left[\mathrm{~m}^{3} / \mathrm{s}\right]$ となる。

図-1 検査空間と PFR (Purging Flow Rate) の概念

$N=\frac{P F R}{V_{p}}\left[\frac{\text { 回 }}{h}\right]$

を局所排出換気回数と定義し、変数 $N$ で表す。

以上から、局所排出換気回数は領域功污染質を排出 する清净化機能を代表する尺度と考えることができる。

\section{2 平均運動エネルギー}

検查空間の平均運動エネルギー $K E$ は次式で算出する。

$K E=\frac{1}{V_{P}} \iiint_{V}\left[\frac{1}{2} \times\left(U^{2}+V^{2}+W^{2}\right)+k\right] d V \quad\left[\mathrm{~m}^{2} / \mathrm{s}^{2}\right]$

ただし、 $U, V, W$ : 平均風速成分 $[\mathrm{m} / \mathrm{s}] 、 k$ : 乱流エネル ギー $\left[\mathrm{m}^{2} / \mathrm{s}^{2}\right]$ 、積分は検査空間全体で行う。

平均風速と乱れは体感温度を低下させ、居住環境のさ

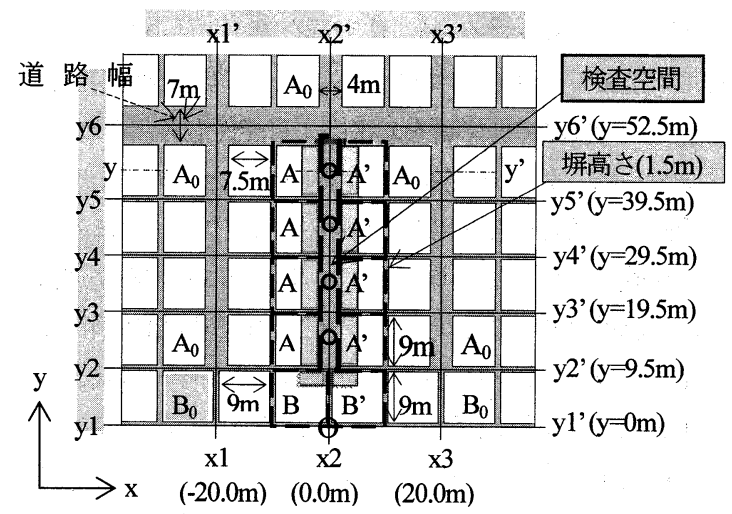

図-4 中心部の建物配置と座標（モデル 1）

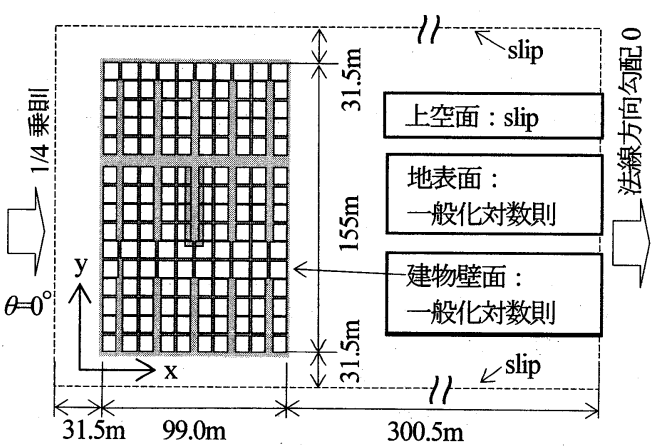

図-5 計算領域と境界条件（モデル 1 、風向 $\mathrm{x}$ ) 
わやかさを助長する。平均運動エネルギーは清涼化機能 を代表する評価尺度と考えられる ${ }^{8,99}$ 。

\section{3. 密集市街地モデル}

まず、今回の密集市街地モデルに用いた建物モデルを 図-2 に示す。建物は 3 階建て、建物高さ $9 \mathrm{~m}$ の住宅を想 定した ${ }^{10)}$ 。建物 $\mathrm{A}$ は $7.5 \mathrm{~m}(\mathrm{x}) \times 9 \mathrm{~m}(\mathrm{y}) \times 9 \mathrm{~m}(\mathrm{z}) 、$ 建物 B は $9 \mathrm{~m}(\mathrm{x}) \times 9 \mathrm{~m}(\mathrm{y}) \times 9 \mathrm{~m}(\mathrm{z})$ で、両建物とも 3 階部分にセットバ ックがある。建物 $A^{\prime} 、 B^{\prime}$ は $\mathrm{z}-\mathrm{y}$ 鉛直平面 $(\mathrm{x}=0)$ に関し て建物 $A 、 B$ と対称な形状を持ち、建物 $A_{0} 、 B_{0}$ はセット バックのない直方体形状と定義する（図-4参照）。

図-3に、これらの建物が建ち並ぶ市街地の 3 種類のモ デルを示す。図-3(a)に風向角 $\theta$ が示してある。まず、モ デル1（図-3(a)）について、図-4に示すその中心部分の 拡大図で説明する。

図-4 中に座標を示す。中心部には $4 \mathrm{~m}$ 道路を挟んで、 建物 A、A'、B、B'の計 10 棟を配置してある。この 10 区画を 1 ブロックとする。周辺に同様のブロックが図-3 のように配置されている。ただし、簡便のため周辺部は セットバックのない建物 $\mathrm{A}_{0} 、 \mathrm{~B}_{0}$ が配置されている。図-4 の中心部の $4 \mathrm{~m}$ 道路は $\mathrm{y}$ 方向に走り、下方、 $\mathrm{y}=9.5 \mathrm{~m}$ の位 置で建物 $\mathrm{B} 、 \mathrm{~B}$ によより塞がれて行き止まりとなっている。 この道路上の地上からセットバック高さまでの領域 $(\mathrm{x}=2 \mathrm{~m} \sim 2 \mathrm{~m} 、 \mathrm{y}=9 \mathrm{~m} \sim 49 \mathrm{~m} 、 \mathrm{z}=0 \mathrm{~m} \sim 5.5 \mathrm{~m})$ を検査空間に指 定する。 $4 \mathrm{~m}$ 道路の $\mathrm{y}$ 方向上端は $\mathrm{y}=49 \mathrm{~m}$ の位置で横 $(\mathrm{x})$ 方向に走る $7 \mathrm{~m}$ 幅の道路に開放されている。また、各区 画の隣地境界線上には、高さ $1.5 \mathrm{~m}$ の塀が立てられてい る。ただし、中心の $4 \mathrm{~m}$ 道路と各敷地の境界には塀はな い。モデルの建物総数は 150 である主1)

市街地モデル 2（図-3(b)）は中心部 4m 道路を挟む建 物 A A, B, B', A' A'（図-4 参照）を一連の建物として連 結したケースである。中心部 $4 \mathrm{~m}$ 道路の換気性状が悪く なることを想定している。

市街地モデル 3 (図-3(c)) は中心部の戸建て住宅群が モデル 1 と同じで、その周りを一連の建物で囲んだケー スである。モデル 1 と 2 の中間の換気性状を想定してい る。しかし、後述のように、実際にはモデル 3 が一番高 い超過確率分布を示した (図-10、11 参照)。

\section{4. 気流数値計算の概要}

\section{1 計算領域と境界条件}

図-5に流入風向角 $\theta=0^{\circ}$ の場合の計算領域と境界条件 を示す。風向に応じて風下となる領域を広くして 9 風向 (後述の流入風向 $i=4 \sim 12)$ の計算を行う（図-9 参照)。
表-1 CFD の計算条件と計算手順

\begin{tabular}{|c|c|}
\hline 乱流モデル & 標淮 $k \varepsilon$ モデル \\
\hline 乱流シュミット数 & 0.9 \\
\hline 差分スキーム & $\begin{aligned} & \text { 拡散項 : } \text { 中心差分スキーム、 } \\
&\text { 移流項 : MARS スキーム*1 (速度, } k, \varepsilon) 、 \\
& 1 \text { 次風上スキーム (濃度) }\end{aligned}$ \\
\hline 流入条件*² & $\begin{array}{l}U=U_{0}\left(z / z_{0}\right)^{\alpha} \quad(\alpha=1 / 4) \\
k=1.5\left(I \times U_{0}\right)^{2}, \quad I=0.1 \\
\varepsilon=C_{\mu}^{1 / 2} k \frac{\partial U}{\partial z} \quad(1-3), \quad c=0 \quad(1-4)\end{array}$ \\
\hline 流出境界 & 法線方向勾配 0 (速度, $k, \varepsilon$, 濃度) \\
\hline 側面 $\cdot$ 上空境界 & Free slip (速度, $k, \varepsilon$, 濃度) \\
\hline 壁面境界 & $\begin{array}{l}\text { 滑面の一般化対数則 }(E=9) \quad(\text { 速度, } k, \varepsilon) \text { 、 } \\
\text { 法線方向勾配 } 0 \text { (濃度) }\end{array}$ \\
\hline 代表速度・長さ & $U_{0}=1 \mathrm{~m} / \mathrm{s}, \quad z_{0}=74.6 \mathrm{~m}$ \\
\hline $\begin{array}{l}\text { 検査空間内の濃度の } \\
\text { 計算手順 }\end{array}$ & $\begin{array}{l}\text { 流れ場を解析した後、検査空間内で污染質 } \\
\text { (passive contaminant) をを } 0.001 \mathrm{~kg} /\left(\mathrm{m}^{3} \mathrm{~s}\right) \text { で一様 } \\
\text { 発生させ、定常濃度分布を計算。 }\end{array}$ \\
\hline \multicolumn{2}{|c|}{$\begin{array}{l}\text { *1 }^{1}: \text { MARS: Monotone Advection and Reconstruction Scheme } \\
\text { *2 }_{2}: U: \text { 主流速度 }(\theta \text { 方向 })[\mathrm{m} / \mathrm{s}], z: \text { 鈆直方向座標 }[\mathrm{m}] 、 k: \text { 乱流エネルギ } \\
{\left[\mathrm{m}^{2} / \mathrm{s}^{2}\right] 、 \varepsilon: \text { エネルギ散逸率 }\left[\mathrm{m}^{2} / \mathrm{s}^{3}\right] 、 I: \text { 乱流強度、 }} \\
c: \text { 濃度 }\left[\mathrm{kg} / \mathrm{kg}^{\prime}\right]\end{array}$} \\
\hline
\end{tabular}

領域は流入境界と主流に平行な $\mathrm{y}$ 方向の両側面境界に 市街地モデルの外側の建物壁面から $31.5 \mathrm{~m}$ の距離を取り、 流出境界には約 $300 \mathrm{~m}$ の距離をとってある。上空境界の 第 1 セルの中心は地表から 74.6m の高さ注2), 13, 14) とした。 上空境界は地表から $82.1 \mathrm{~m}$ となる。流入風は $1 / 4$ 乗則の 速度プロファイルを与え、高さ $74.6 \mathrm{~m}$ で風速 $1 \mathrm{~m} / \mathrm{s}$ とする。 CFD の計算条件と検査空間内の濃度の計算手順を表 -1 に示す。数值解析は STAR-CD を使用し、SIMPLE 法 による定常解法、空間差分スキームは速度と乱流量に MARS スキームを適用、濃度に対しては一次風上スキー ムを適用した。局所排出換気回数の算出に検査空間で污 染質発生源を設定し濃度計算を行うため、二次精度スキ ームでは計算不安定が生じるためである。乱流モデルは 標準 $k-\varepsilon$ モデルを使用した。他の条件等は表-1 参照。

\section{2 検査空間の風速分布}

図-6 はモデル 1 における流入風向角 $\theta=0^{\circ}$ の場合の検 査空間の $\mathrm{z}$-x 鉛直断面（図-4の $\mathrm{y}$-y'断面）のCFDによる 風速ベクトルである。断面は検査空間 (4m 道路) の開 口部に接続する $7 \mathrm{~m}$ 道路に一番近い建物の中央に位置す る。この風速のスカラ值は風洞実験結果とオーダ的によ い一致を示した ${ }^{12)}$ 。

風向角 $0^{\circ}$ では、セットバック領域に時計回りの強い 循環流が生じ、セットバック高さ $5.5 \mathrm{~m}$ でエアカーテン様 にセットバック領域と下部の検査空間領域を仕切ってい る。そして検査空間には反時計回りの循環流が誘引され ている。よって、このセットバックのあるモデルの局所 排出換気回数は、セットバックのない場合と比べて低下 していると考えられる。換気性状の向上を図って設定し 
たつもりのセットバックが、風向角によっては、換気に 有効には働かない場合もあることが興味深い8)。

\section{5. 風向・風速の統計データに基づく超過確率の計算法}

\section{1 市街地の方位と流入風向}

図-7に市街地モデルの方位、流入風向番号、流入風向 角の定義を示す。建物モデルの壁面の $\beta$ と記した矢印の 方向をこの市街地モデルの方位 $\beta$ と定義し、方位番号で 表す。図-7では $\beta=2$ である。モデルの流入風向に、 $\beta$ 方 向を $i=0$ として時計回りに $i=15$ まで番号 $i$ を付ける。上 空の風向を $n$ とすると流入風向番号は $i=n-\beta$ と書ける。

\section{2 局所排出換気回数に基づく超過確率}

高さ方向の風速プロファイルを表-1、式(1-1)のように 設定し、高さ $h_{T}[\mathrm{~m}]$ における上空風速が $v_{T}[\mathrm{~m} / \mathrm{s}]$ で、かつ 風向が市街地モデルの流入風向番号 $i$ であるときの CFD で計算した検査空間の局所排出換気回数を $N_{i}^{v_{T}} \quad(i=0 \sim 15)$ とし、局所排出換気回数の指定值を $N_{S}$ とする。

局所排出換気回数 $N_{S}$ を実現するための高さ $h_{C}$ の上空 風速 $v_{C}$ は式(5)となる。

$$
v_{C}=\frac{N_{S} \times v_{T}}{N_{i=n-\beta}^{v_{T}}}\left(\frac{h_{C}}{h_{T}}\right)^{\alpha}[\mathrm{m} / \mathrm{s}]
$$

したがって、指定した換気回数值 $N_{S}$ に対する換気回数 基準の超過確率 ${ }^{8}$ は式(6)で表される。

$$
\begin{aligned}
& P\left({ }^{c} N>N_{S}\right)=\sum_{n=0}^{15} A_{C}^{a_{n}} \times \exp \left\{-\left(\frac{v_{C}}{C_{C}^{a_{n}}}\left(\frac{h_{C}}{h_{T}}\right)^{\alpha}\right)^{K_{C}^{a_{n}}}\right\} \\
& =\sum_{n=0}^{15} A_{C}^{a_{n}} \times \exp \left\{-\left(\frac{N_{S} \times v_{T}}{N_{i=n-\beta}^{v_{T}} \times C_{C}^{a_{n}}}\left(\frac{h_{C}}{h_{T}}\right)^{\alpha}\right)^{K_{C}^{a_{n}}}\right\}[\%]
\end{aligned}
$$

ただし、 $A_{C}^{a_{n}}$ : 対象都市上空の風向 $a_{n}$ の発生頻度（風 配) $[\%]^{13)} 、 C_{C}^{a_{n}}($ 尺度係数 $[\mathrm{m} / \mathrm{s}]) 、 K_{C}^{a_{n}}$ (形状係数 $\left.[-]\right)$ : 同ワイブル係数 ${ }^{13)} 、 h_{C}$ : 対象都市の風速計設置高さ $[\mathrm{m}] 、$ ${ }^{C} N$ : 検查空間の換気回数、添字 $\mathrm{C}$ : 対象都市を表す。

図-8に4 都市の風配、尺度係数、形状保数を示寸 ${ }^{13)}$ 。

\section{6. 計算結果と考察}

\section{1 検査空間の局所排出換気回数}

図-7 の流入風向番号 $i=0 \sim 15$ の各方向に地上高さ $74.6 \mathrm{~m}$ において風速を $v_{T}=1.0 \mathrm{~m} / \mathrm{s}$ とする流入風のプロファイル

（表-1、式(1-1)）を課して、市街地内の検查空間の局所 排出換気回数 $N_{i=n-\beta}^{v_{T}}$ をCFDにより計算する。市街地モデ ルは道路方向（y 軸）に関して対称であるので、実際に
風向 ( $\mathrm{x}$ 方向、 $\theta=0^{\circ}$ )

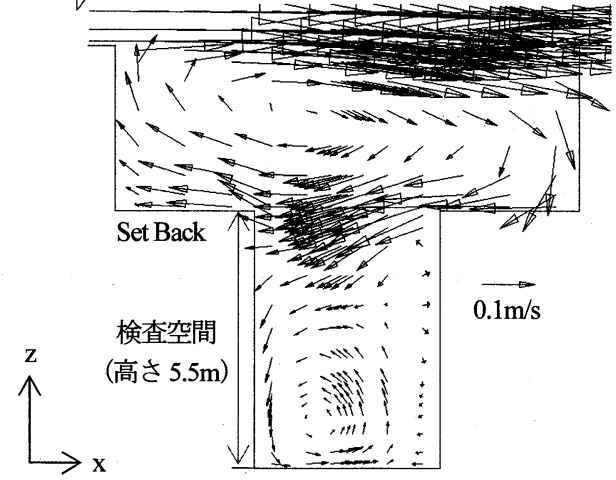

図-6 検査空間（中心部 $4 \mathrm{~m}$ 道路）の速度ベクトル (モデル 1、y=44.5m、y-y’断面)

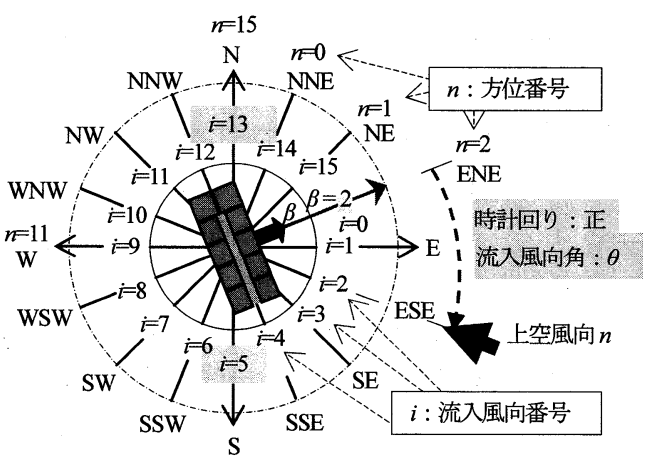

図-7＼cjkstart市街地モデルの方位と流入風向

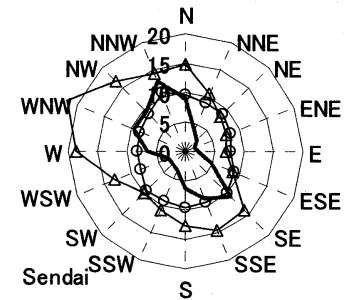

(a) 仙台 $\left(h_{C}=52.0 \mathrm{~m}\right)$

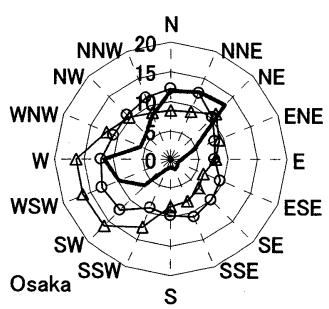

(c) 大阪 $\left(h_{C}=22.9 \mathrm{~m}\right)$

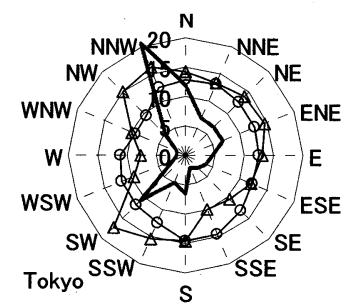

(b) 東京 $\left(h_{C}=74.5 \mathrm{~m}\right)$

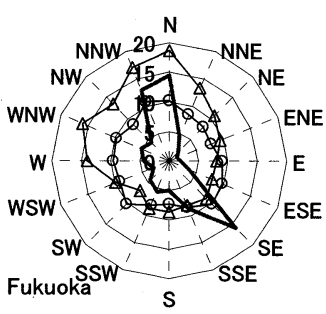

(d) 福岡 $\left(h_{C}=24.4 \mathrm{~m}\right)$
図-8 都市の風配とワイブル係数 ${ }^{13)}$

$\left(一: A_{n}[\%], \quad \triangle: C_{n} \times 4[\mathrm{~m} / \mathrm{s}], \quad \bigcirc: K_{n} \times 5[-]\right)$

は局所排出換気回数は

図-9に 3 種類のモデルの流入風向別の局所排出換気回 数 $N_{i=n-\beta}^{v_{T}}$ のCFDによる計算結果を示す。 
モデル 1 は、市街地形状に $1 \mathrm{~m}$ 閒隙からの流入をさま たげる要素がないため、風向の影響が少ない局所排出換 気回数の分布となっている。

モデル 2 は隙間のない一連の建物であり、 $4 \mathrm{~m}$ 道路 (検 查空間）に直交する風向 $0 、 8$ で換気能力が最小となる。 風向 10 14 で大なる局所排出換気回数を示す。

モデル 3 は、「 $1 \mathrm{~m}$ 間隙」のある建物群を一連の建物で 囲ったモデルである。 $4 \mathrm{~m}$ 道路（検查空間）に直交する 風向 0、8（図-4の $\mathrm{x}$ 軸の正、もしくは負の方向）の換気 能力がモデル 2 の最小值より大となり、モデル 1 と同じ レベルに迫っている。これは下流側の一連建物が間隙か らの流入を強くする性状を示すことに起因している ${ }^{11)}$ 風向 10 14 でモデル 2 とほぼ同じ分布の大なる局所排出 換気回数を示す。

風向 12 においてモデル $1 、 2 、 3$ とも最大の局所排出換 気回数を示している。この風向 12 は $4 \mathrm{~m}$ 道路 (検査空間) の閉鎖側（図-4の $\mathrm{y}$ の負の方向）が風上側である。今回 の密集市街地モデルでは、この風向において道路の閉鎖 側の建物 BB'を超えた気流が検査空間内の空気をよく上 空に誘引し、検查空間の開口（下流の $7 \mathrm{~m}$ 道路側）側か らの流入を強く促進する換気性状を示す。

\section{2 市街地モデルの超過確率分布}

密集度の異なる 3 種類の市街地モデルの超過確率分布 を仙台、東京、大阪、福岡の 4 都市について計算した。

超過確率の計算は式(6)を用いて行う。式(6)中の局所排 出換気回数 $N_{i=n-\beta}^{v_{T}}$ は、地上高さを $h_{T}=74.6 \mathrm{~m}$ の風速を $v_{T}=1$ $\mathrm{m} / \mathrm{s}$ とした結果 (図-9) を使う。また、式中の風配 $A_{C}^{a_{n}}$ 、 ワイブル係数 $C_{C}^{a_{n}} 、 K_{C}^{a_{n}}$ は、風速計設置高さ $h_{C}$ で測定さ れた風速データに基づく統計資料 ${ }^{13)}$ である。局所排出換 気回数 $N_{i}^{v_{T}}$ (図-9） と $h_{T}=74.6 \mathrm{~m} 、 h_{C}$ (図-8）を、式(6) に与えて、都市における超過確率を計算する注2), 13，14)。

\section{2.1 各都市の方位別超過確率分布注3)}

図-10 は、4 都市における検査空間の方位別超過確率で ある。局所排出換気回数をパラメータとして、横軸を方 位番号にとって超過確率の分布を示している。市街地壬 デルは方位による差異が小さいのでこの表現を採用した。 後述の図-11 のように横軸に局所排出換気回数をとった 表示にすると、16 方向の分布が集中して方位による差異 が識別不可能となるためである。

図-8 を参照しながら各都市の超過確率分布を考える。

図-10(b)の東京の超過確率分布を先に検討する。局所 排出換気回数 15 回/h では、 3 モデル共にほぼ一定の超過 確率 95\%程度となり、モデル方位による差はほとんどな

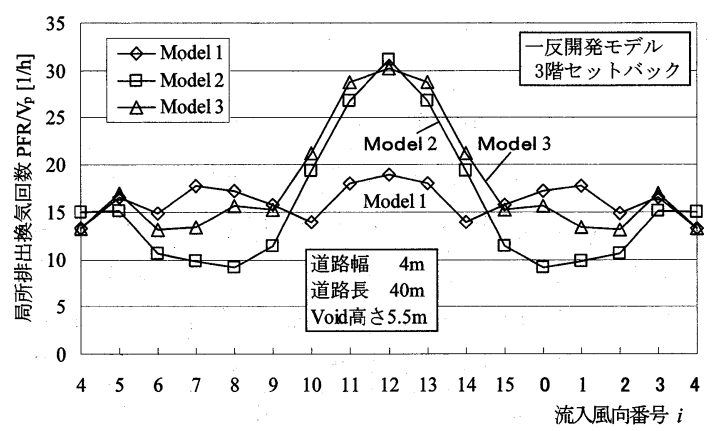

図-9 風向別の局所排出換気回数

い。東京では、この程度の換気回数は年間を通して風向 によらずほぼ担保可能であることを示す。局所排出換気 回数が大になるに連れて、モデル方位による差異が大に なり、局所排出換気回数 60 回/h で、この図では、最も 差が広がっている。この傾向は他の3 都市にも見られる。

図-10(b)で、超過確率のピークはモデル方位 ESE $(n=4)$ 付近にある。この方位では、NNW、N、NNE、NE、ENE （流入風向 $i=10 \sim 14 ）$ が検査空間の閉鎖側となり、閉鎖 側の風が強いと換気能力が大になる。卓越風向 NNW、N がこれに含まれ、NNE、NE、ENE も 7\%ほどの頻度を持 つので、このモデル方位付近でピークを示すのである。 また、後述の 3 都市に比べて、低い換気回数の超過確率 が高いのは、尺度係数が $3.3 \mathrm{~m} / \mathrm{s}$ 前後であまりバラつかず に分布しているからである（図-8 (b)参照)。

図-10(a)は仙台の超過確率分布である。局所排出換気 回数 15 回/hでは、3 モデル共にほぼ一定の超過確率 $90 \%$ 程度であり、東京より低い。換気回数 30 回 $/ \mathrm{h}$ でも東京 より低い傾向を示す。換気回数 60 回 $/ \mathrm{h}$ で同じレベルに なり、90回/hでは仙台の方が高い超過確率を示す。これ は、尺度係数がいびつな楕円形で小さい係数值から大き い值まで分布しており、かつ分布の長軸方向と風配の長 軸方向がほぼ一致しているので、低い換気回数から減衰 をはじめ、高い換気回数まで超過確率の減衰しない方位 が残るからである。

モデルの方位による超過確率の差異は東京より少ない。 仙台の風配に鋭い卓越風向がないためである。

図-10(c)の大阪では、東京とほぼ同様の超過確率分布 を示すが、方位による変化が東京より少し大きい。

また、大阪の超過確率のピークが、東京と同様にモデ ル方位 E、ESE 付近にある。これは、このモデル方位で 大阪の卓越風向 $\mathrm{N} 、 \mathrm{NNE} 、 \mathrm{NE}$ が検査空間の閉鎖側にな ることも主たる要因の一つである。

図-10(d)の福岡は、換気回数 15 回 $/ \mathrm{h} 、 30$ 回 $/ \mathrm{h}$ では、東 京より超過確率が低い。60回/h でほぼ同じレベルにあ 


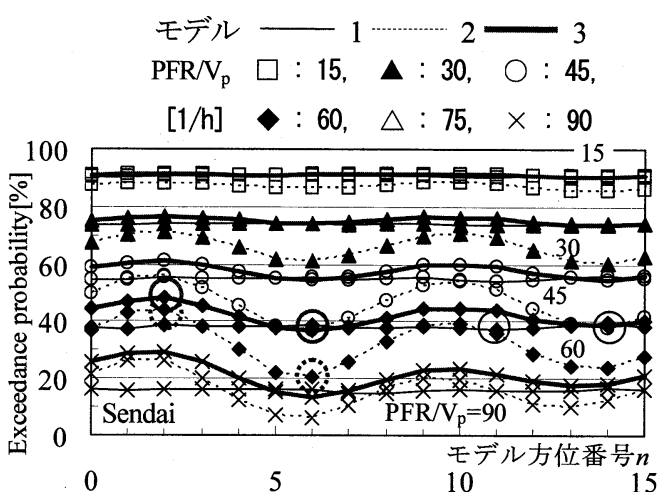

(a) 仙台

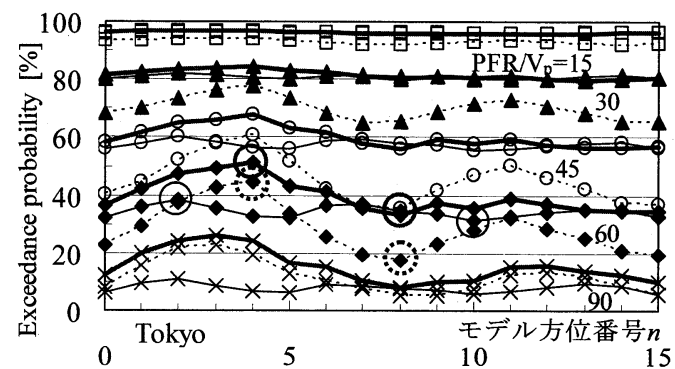

(b) 東京

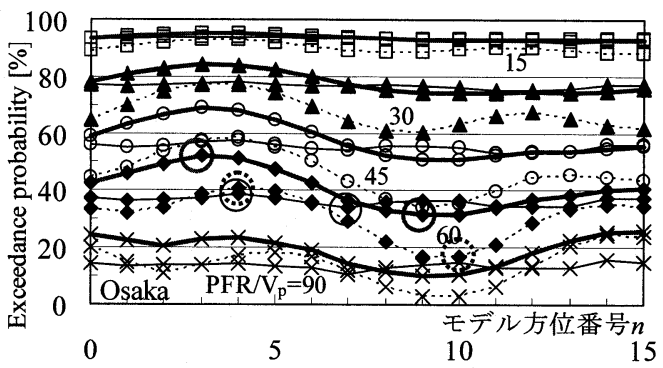

(c) 大阪

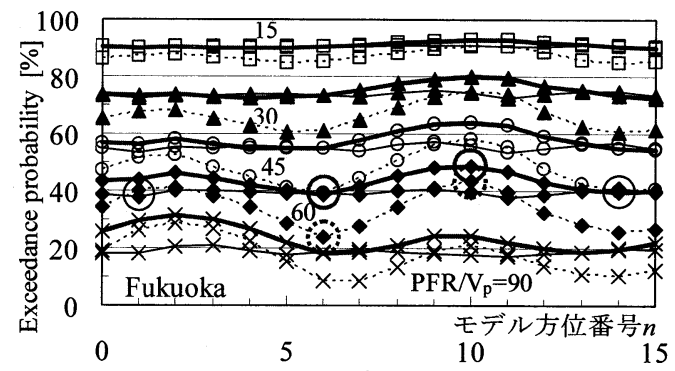

(d) 福岡

図-10 Void の方位別超過確率

(最大・最小值発生位置: モデル $1: 0 、 2: \vdots$ : $3:$ ）

る。90回/hでは、まだ $20 \%$ 前後と東京より高い。これは 仙台と同様に尺度係数值がバラついているためである。 超過確率の方位による変動は 4 都市の中で最も少ない。

図-10 中に、60 回/hにおける超過確率の最大值、最小 值を与える方位を丸印で示す (6.2.3 項参照)

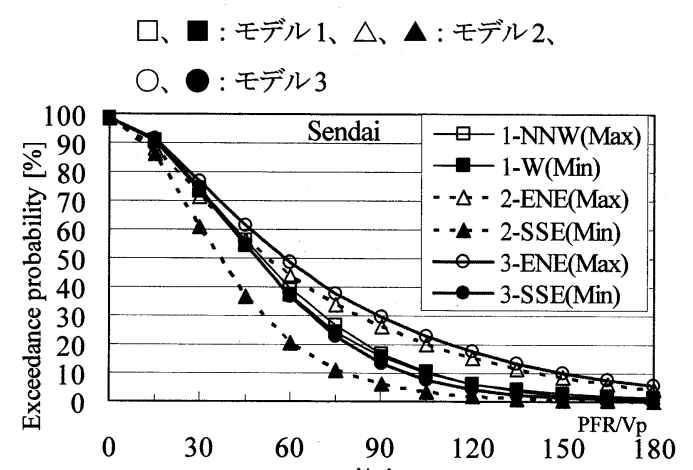

(a) 仙台

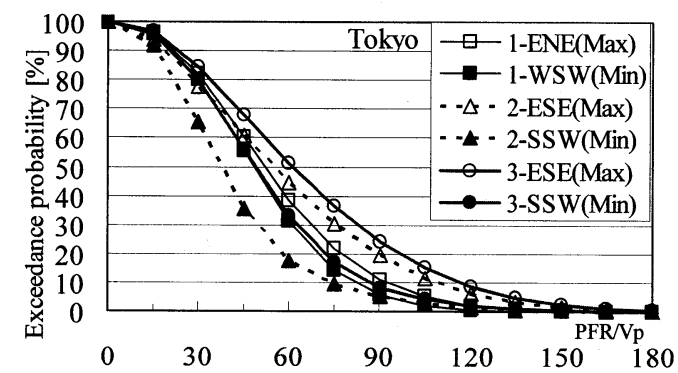

(b) 東京

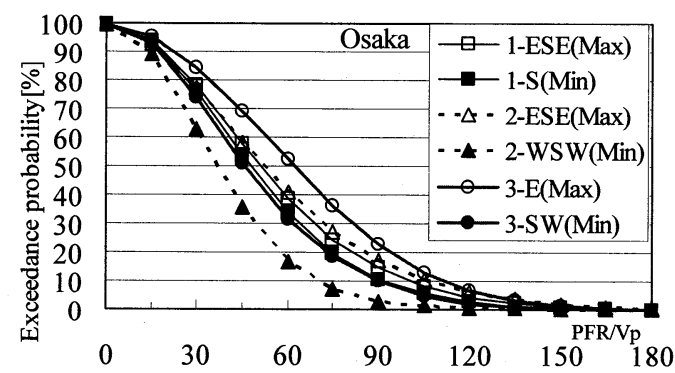

(c) 大阪

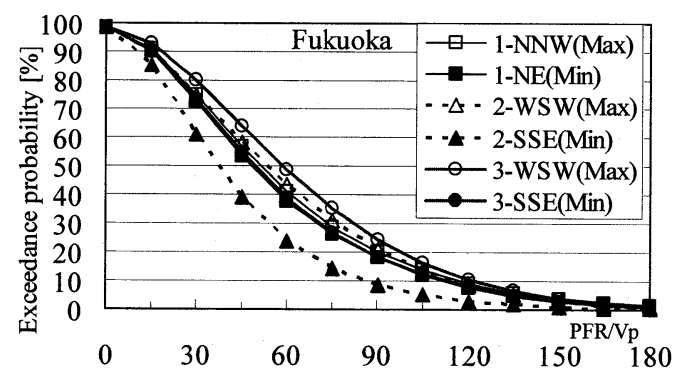

(d) 福岡

図-11 都市別の超過確率の比較 $(\mathrm{PFR} / \mathrm{Vp}=60[1 / \mathrm{h}]$ において、最大・最小超過確率 を示す方位の超過確率分布)

\section{2.2 方位別超過確率分布に対する密集度の影響}

東京 (図-10(b)) の局所排出換気回数 60 回/hについて、 密集度の異なる 3 種のモデルの換気性状の違いを考える。

モデル 1 は、方位による超過確率分布の変化が最も少 ない。これは戸建て住宅の「1m 間隙」が、換気に対し て有効に機能していることを示す。モデル 2 は、間隙を 
なくした一連の建物である。方位による超過確率の差異 は大きく、最大と最小の差で、20\%を超えている。モデ ル 3 は戸建て住宅を一連の建物が取り囲んだモデルであ り、方位による違いはモデル 1 と 2 の中間となっている。 しかし、超過確率はモデル 1 より大きい分布を示す (図 -10(b)の一と一)。戸建て住宅群を取り囲む一連の建物が 下流側からの流入を増加させているからである ${ }^{11,12) 。 ~}$

3 種のモデルによる差異は、程度の違いは見られるが、 他の都市においても同様に観察される。

以上をまとめると、モデル 1 は方位による変動が少な く、モデル 2 が一番大きい。モデル 3 は両者の中間の変 動を示すが、超過確率は一番高い分布を示す。

\section{2.3 都市別の超過確率分布の比較}

さて、図-10 には情報は全て盛り込まれているのであ るが、この図から都市間の特性を判別するのは少々困難 である。そこで、別の切り口から超過確率の変動範囲を 表示して都市別の超過確率分布を比較・検討する。

図-11 は 3 種の市街地モデルに設定した検査空間の超 過確率分布の方位による変動範囲の都市別の比較である。 横軸は局所排出換気回数にとってある。図-10 から、局 所排出換気回数が 60 回/h であるときの最大超過確率を 示寸方位と最小超過確率を示す方位を選定して、これら の方位の超過確率分布を、各都市の超過確率分布のモデ ル方位による変動範囲をおおむね表すものとして洠4)、都 市毎に示してある。この方位の選定は一貫した方位に対 する超過確率分布を使用して検討するためである。

図-11(b)は東京の超過確率のモデル方位による変動範 囲である。モデル 1 の方位による最大と最小分布の差異 (口とロの差) は小さい。これに対し、モデル 2 では大 なる差異 $(\triangle 、 \boldsymbol{\Delta})$ を示す。モデル 3 は、両者の中間と なる差異 $(O 、 の)$ を示す。しが、モデル 3 は最も高 い最大超過確率分布（○）を示す。

図-11(a)は仙台の超過確率の変動範囲である。変動の 幅は、局所排出換気回数が 90 回/h までは東京より少な いが、これ以上では減衰が遅く、モデルによる差異も東 京より大きくなる。図-11(c)は大阪の超過確率の範囲で ある。大阪は少しモデルによる差異の幅が広いが、東京 とよく似た分布を示している。図-11(d)は福岡の超過確 率の幅である。福岡は他の 3 都市より、モデルによる差 異が小さい。

以上のように、市街地モデルの方位別特性を見るには、 図-10 の表示を使用し、モデルの都市別の換気能力を比 較する場合は図-11 の表示が便利である。また、モデル 間の違いを見るには、図-10、11 を併用するとよい。

\section{2.4 超過確率 $85 \%$ と $15 \%$ に対する局所排出換気回数}

表-2 に超過確率 $85 \%$ と $15 \%$ に対応する各市街地モデ ルの 4 都市の最小局所排出換気回数とそれを与えるモデ ルの方位を示す注5)。
表-2 超過確率 $15 \%$ 、85\%に対応する最小局所排出換気回数

\begin{tabular}{|c|c|c|c|c|c|c|}
\hline \multirow{2}{*}{ 都市 } & \multicolumn{2}{|c|}{ モデル 1} & \multicolumn{2}{c|}{ モデル 2} & \multicolumn{2}{c|}{ モデル 3} \\
\cline { 2 - 7 } & $85 \%$ & $15 \%$ & $85 \%$ & $15 \%$ & $85 \%$ & $15 \%$ \\
\hline \multirow{2}{*}{ 仙台 } & $\mathrm{NNE}$ & $\mathrm{SSW}$ & $\mathrm{NNW}$ & $\mathrm{SSE}$ & $\mathrm{NNW}$ & $\mathrm{SSE}$ \\
\cline { 2 - 7 } & 20.45 & 89.59 & 15.36 & 67.49 & 20.36 & 86.98 \\
\hline \multirow{3}{*}{ 東京 } & $\mathrm{NNE}$ & $\mathrm{WSW}$ & $\mathrm{NNW}$ & $\mathrm{SSW}$ & $\mathrm{NW}$ & $\mathrm{SSW}$ \\
\cline { 2 - 7 } & 26.24 & 74.25 & 19.83 & 63.54 & 26.13 & 77.63 \\
\hline \multirow{2}{*}{ 大阪 } & $\mathrm{W}$ & $\mathrm{S}$ & $\mathrm{N}$ & $\mathrm{WSW}$ & $\mathrm{NW}$ & $\mathrm{SW}$ \\
\cline { 2 - 7 } & 22.76 & 81.71 & 16.78 & 62.09 & 21.99 & 80.19 \\
\hline \multirow{2}{*}{ 福岡 } & $\mathrm{NE}$ & $\mathrm{W}$ & $\mathrm{SE}$ & $\mathrm{SSE}$ & $\mathrm{ESE}$ & $\mathrm{NW}$ \\
\cline { 2 - 7 } & 19.86 & 94.94 & 14.82 & 73.97 & 19.57 & 96.86 \\
\hline
\end{tabular}

注）方位記号は最小局所排出換気回数 $[$ 回/h]を与えるモデルの方位。

$15 \%$ に対応する局所排出換気回数とは、検査空間がそ の局所排出換気回数以上の換気能力を発揮する確率が 1 週間のうち 1 日程度ある、逆にこれ以下になる可能性が 6 日あるということを表す。 $85 \%$ に対応する局所排出換 気回数とは、この換気回数以上の換気能力が、 1 週間の うち 6 日程度は確保されることを表す ${ }^{15)}$ 。例えば表から、 東京のモデル 1 では、週に 6 日は約 26 回/h 以上の局所 排出換気回数が確保され、週に 1 日は約 74 回 $/ \mathrm{h}$ 以上の 換気能力が期待出来るということが分る。

これに対し、福岡のモデル 1 では、週に 6 日間、期待 できる換気回数は、ほぼ 19 回 $/ \mathrm{h}$ 以上と東京より少なく、 週に 1 日では約 94 回/h以上と東京に比べ高い值となる。

仙台のモデル 1 では、週に 6 日は約 20 回/h 以上と東 京より低く、週に 1 日は約 89 回/h 以上と東京より高い。

大阪も同じ傾向を示すが、週に 6 日は約 22 回 $/ \mathrm{h}$ 以上、 週に 1 日は約 81 回 $/ \mathrm{h}$ 以上と東京との差は少ない。

表-2により、都市の換気能力に関して、具体的な局所 排出換気回数值によって比較・評価することが可能とな る。表-2 は都市の風による清净化能力の一つの評価方法 を示している。この週 6 日、週 1 日の発生確率とは、ま さに人間の生活パターンとよく調和した確率条件である。

\section{7. 結論}

密集度の異なる 3 種類の市街地モデルの局所排出換気 回数に対する超過確率分布を 4 都市について検討した。

モデルによる差異は 4 都市でほぼ同様の傾向を示した。 戸建て建物で構成されたモデル 1 では、建物間の間隙が 有効に働き、市街地方位による換気性能の差異は少ない。 建物間の間隙のない一連の建物では (モデル2)、市街地 方位による差異は大きくなるが、袋小路の道路の一方の 開口が有効に働き、換気性能はさほど低下しない。一連 の建物で囲まれた戸建て住宅群（モデル 3）では、モデ ル方位の影響はモデル 1 と 2 の中間になるが、必ずしも 換気性能は低下せず、一連の建物が戸建て住宅群の換気 能力を強める場合もある。

都市間の差異は、今回の検討では、都市の風況特性 (風 配、ワイブル係数) のみで決る。都市の強い卓越風向の 存在がモデル間の違いを広げ、都市の尺度係数のバラつ 
きが超過確率分布の局所排出換気回数に対する減衰勾配 に影響を与える。これらがそのまま都市間の差異になる。

また、超過確率 $15 \%$ 、85\%に対応する都市・モデル別 の局所排出換気回数值を算出し、具体的な換気回数值に よって比較・評価する一つの方法を示した。

研究の第一段階として、平均的な風向・風速データに 基づく風向出現頻度およびワイブル係数を使用して、ワ イブル分布を仮定した換気回数に対する超過確率に基づ く評価手法を示した。弱風に対する統計的性質の検討は、 弱風データの測定も含めて今後の課題である。

\section{謝辞}

本研究の遂行に当たってご協力を頂いた国土交通省東 北地方整備局 副局長後藤隆之氏、国土交通省国土技術政 策総合研究所都市研究部 都市計画研究室長明石達生博 士、国土交通省土地・水資源局土地政策課土地市場企画 室 企画専門官豊原寛明氏、独立行政法人建築研究所 環 境研究グループ長澤地孝男博士、国土交通省国土技術政 策総合研究所都市研究部 都市開発研究室主任研究官勝 又済博士、同都市計画研究室主任研究官石井儀光博士に 謝意を表す。

\section{参考文献}

1) Melbourne W. H. :Criteria for environmental wind conditions, Journal of Industrial Aerodynamics, Vol. 3, pp. 241-249 (1978).

2) 村上周三, 岩佐義輝, 森川泰成 : 市街地低層部における風の 性状と風環境評価に関する研究（III）居住者の日誌による風環 境調査と評価尺度に関する研究，日本建築学会論文報告集，第 325 号, pp. 74-84, 1983 年 3 月

3) Ohba M., Kobayashi N., and Murakami S. : Study on the assessment of environmental wind conditions at ground level in a built-up area -based on long-termmeasurements using portable 3-cup anemometers-, Journal of Wind Engineering and Industrial Aerodynamics, Vol. 28, pp. 129-138 (1988).

4) Isyumov N., Davenport A. G : The ground level wind environment in built-up areas, Proceedings of fourth international conference on Wind Effects on Buildings and Structures, London, pp. 403-422 (1975).

5) Sandberg M. Sjöberg M. : The Use of Moments for Assessing Air Quality in Ventilated Rooms, Building Environment, Vol.18, pp.181-197, (1983).

6) 加藤信介, 伊藤一秀, 村上周三 : 換気システムを変化させた場合 の規淮化居住域濃度, Visitation Frequency, Purging Flow Rate 統的解析, 第 1 報一オフィス空間を対象とした居住域換気効率 の評価に関する研究, 空気調和・衛生工学会論文集, No. 78, pp. $45-56,2000$ 年 7 月

7) 伊藤一秀, 加藤信介, 村上周三 : 平均拡散場解析による Visitation Frequency, Purging Flow Rate の解析, 不完全混合室内の居住域 換気効率の評価に関する研究，日本建築学会計画系論文集，第
529 号, pp. 31-37,2000年3月

8)卜震, 加藤信介, 石田義洋, 黄弘, 他 : 市街地の風環境の研究 (そ の 1）通風換気性能に関する超過確率に基づく風環境評価法 の提案とその空堀モデルへの適用, 日本建築学会会計画系論 文集, 第629号,2008年7月

9) 加藤信介 : 都市境界層の鉛直乱流輸送能力に関係づけられた市 街地ボイド空間の風環境評価, 日本建築学会, 第 15 回空気シン ポジウム,pp. 63-66,2006 年9月 6 日

10) 澤地孝男, 加藤信介, 豊原寛明, 勝又済, 石井儀光, 石田義洋, 黄弘 : 市街地の風環境の研究（その 3）, 密集市街地における 通風・換気性能の検討のためのモデル設定, 日本建築学会大会 学術講演梗概集, D2,pp. 785-786,2006 年9月

11) 石田義洋, 加藤信介, 黄弘, 豊原寛明, 澤地孝男, 勝又済, 石 井儀光 : 市街地の風環境の研究 (その4), 密集市街地モデル 内のボイドの通風・換気性能の予備検討, 日本建築学会大会 学術講演梗概集, D2, pp. 787-788, 2006 年

12) モハメドバディ, 加藤信介, 石田義洋, 黄弘, : 市街地の風 環境に関する研究（その 2) 局所排出換気回数に関する超過 確率に基づく風環境評価の密集市街地モデルへの適用，日本 建築学会会計画系論文集，(投稿中）

13）風工学研究所, ビル風の基礎知識, 鹿島出版会, pp. 110-117, 2005 年

14) 風工学研究所, 新ビル風の知識, 鹿島出版会,pp. 189, 1989 年

15) 加藤信介: 巻頭言 市街地の風通しはどのように計られるか 日本風工学会誌第 32 巻第 4 号, PP. 421-423, 2007 年 10 月

注

注 1) 空間分割は $\theta=0^{\circ}$ の場合、領域全体で $107(\mathrm{x}) \times 136(\mathrm{y}) \times 36$ (z) 分割である。建物 $\mathrm{A}, \mathrm{A}^{\prime}, \mathrm{A}_{0}$ は $7(\mathrm{x}) \times 5(\mathrm{y}) \times 21$ (z) 分割、 $\mathrm{B}, \mathrm{B}^{\prime}, \mathrm{B}_{0}$ は $9(\mathrm{x}) \times 6(\mathrm{y}) \times 21(\mathrm{z})$ 分割、中心部の $4 \mathrm{~m}$ 道路は横断 方向に 9 分割である。計算格子の地表面第一点の高さは $0.1 \mathrm{~m}$ である。

注 2) 東京では、 $h_{T}=74.5 \mathrm{~m}$ であるが、これは先に文献 ${ }^{14)}$ により 東京の風速計設置高さを $h_{C}=h_{T}=74.6 \mathrm{~m}$ として風速を $v_{T}=1 \mathrm{~m} / \mathrm{s}$ として CFD 計算を済ませてしまってから、文献 ${ }^{13)}$ の新しい 統計値 (東京の風速計設置高さ $h_{C}=74.5 \mathrm{~m}$ ) を採用したためで ある。もちろん、流入プロファイルを同一に設定する限り、 計算結果に差異は生じない。

注 3) ここで、尺度係数 $\left(C_{C}^{a_{n}}\right)$ と形状係数 $\left(K_{C}^{a_{n}}\right)$ が超過確 率の減衰勾配に与える影響を確認する。 $C_{C}^{a_{n}}$ が 16 方向同一 であると、式(6)の指数関数が同じ風速（に対応した局所排出 換気回数) で一斉に減衰するので、超過確率の換気回数に対 する减衰が急激になる。 $C_{C}^{a_{n}}$ の值がバラついていると、減衰 が異なる風速で始まるので減衰が緩やかになる。また、形状 係数 $K_{C}^{a_{n}}$ が大であるとその風向 $n$ の減衰が急激になる。

注 4) 正確には、最小・最大值を与える方位は、局所排出換気 回数值によって入れ替わる。より詳細な検討を行うには、必 要な局所排出換気回数をパラメータにとって、超過確率分布 を算出して比較するとよい注 5)。超過確率分布は、図-9に示 した流入風向別の局所排出換気回数さえ計算してあれば、表 計算ソフトで容易に算出可能である。

注 5) 最小の局所排出換気回数を示す方位を選定してある。図 -11 の最小方位とは必ずしも一致しないが、局所排出換気回 数值はほぼ等しくなる。 